\title{
Comparative ANALYsis of COMMON MODE Voltage, BEARING CURRENT AND SHAFT Voltage of DiOde Clamped SPWM MULTILEVEL INVERTER FED INDUCTION MOTOR
}

\author{
Rajendra K. Dhatrak ${ }^{1}$, Rajesh K. Nema ${ }^{2}$ and Dinesh M.Deshpande ${ }^{3}$ \\ ${ }^{1}$ Research Scholar, Department of Electrical Engineering, MANIT, Bhopal, Madhya \\ Pradesh, India \\ ${ }^{2}$ Professor, Department of Electrical Engineering, MANIT, Bhopal, Madhya Pradesh, \\ India \\ ${ }^{3}$ Professor, Department of Electrical and Electronics Engineering, SIRTS, Bhopal, M P, \\ India
}

\begin{abstract}
Variable Speed Drives (VSD) due to their high dynamic performances are growing importance in industrial applications. PWM inverters are mainly responsible for VSDs dynamic operation but they give rise to bearing currents. Parasitic capacitances present in machine doesn't create problem at lower frequencies, but at higher carrier frequencies they provide charging path and builds up shaft voltage. When this voltage reaches to a dielectric breakdown voltage of lubricant film, it breaks down, and develops a high discharge bearing current which damage the bearings in a very short time of operation. Multilevel inverter is one of the options to reduce this problem. This paper is an attempt to investigate the effects on CMV, bearing voltage, bearing currents and total harmonic distortion (THD); by diode clamped multilevel (three, five and seven level) and conventional inverter fed induction motor. In this paper phase disposition (PD), sinusoidal pulse width modulation (SPWM) technique is used.
\end{abstract}

\section{KEYWORDS}

Bearing Current, $\quad$ Bearing Voltage, $\quad$ Common Mode Voltage, $\quad$ Total Harmonic Distortion

\section{INTRODUCTION}

In variable speed drive system front end act as rectifier and inverter at the motor end is a variable voltage variable frequency AC source. Ideally inverter output voltage is purely sinusoidal but in practical inverter output is non sinusoidal with harmonics contents. For low and medium power application this type of output voltage may be tolerated but for high power application purely sinusoidal waveform with low THD is expected. The conventional PWM voltage source inverters (VSI) have minimum number of devices, simple circuit topology and control. Their major drawbacks are presence of harmonics close to the switching frequency [1]. They also have a major problem of CMV which gives rise to shaft voltages and bearing currents [2],[3]. For better operation of induction motor CMV and THD should be reduced. Some of the approaches to reduce harmonics are application of different types of filters [4], dual bridge inverters [5], four leg inverters [6], by improving modulation techniques [7],[8] etc. 
Now a day a multilevel inverter is better options to reduce CMV and THD [7], [8]. The output voltage of MLI is stepped in smaller increments. Due to this harmonics at low switching frequencies are reduced hence reducing the switching losses. Multilevel inverters start from three levels. As the number of level increases THD and CMV both decreases with increase in circuit complexity. Hence practically it is possible to design MLI up to seven level.

In the previous papers the study has been limited to common mode reduction using multilevel inverter [7], [8]. In this work, effect of multilevel inverter on bearing current, shaft voltages and harmonic distortion in line voltages along with CMV is studied. An inverter driven motor model is simulated to make comparative study of conventional two, three, five and seven level diode clamped multilevel inverter. The comparison is done on the basis of how CMV, bearing voltages, bearing currents and THD contents in voltage waveforms, varies with the increase in inverter level. The motor parameters are actually measured in the laboratory with the help of LCR meter. Same values of parameters are used for simulation studies. A motor having facility to measure bearing currents, shaft voltages and parasitic capacitances is specially designed for this work.

\section{Common Mode Voltage}

CMV is defined as the voltage between neutral point of the load and the system ground. It may also define as the voltage between neutral point of the load and the dc midpoint [7], [8]. The generalized drive system can be represented as fig.1.

Where $\mathrm{V}_{\mathrm{ag}}, \mathrm{V}_{\mathrm{bg}}$ and $\mathrm{V}_{\mathrm{cg}}$ are the voltages between ground to phase and $\mathrm{V}_{\mathrm{ng}}$ is the voltage between neutral of the motor and system ground i.e. CMV.

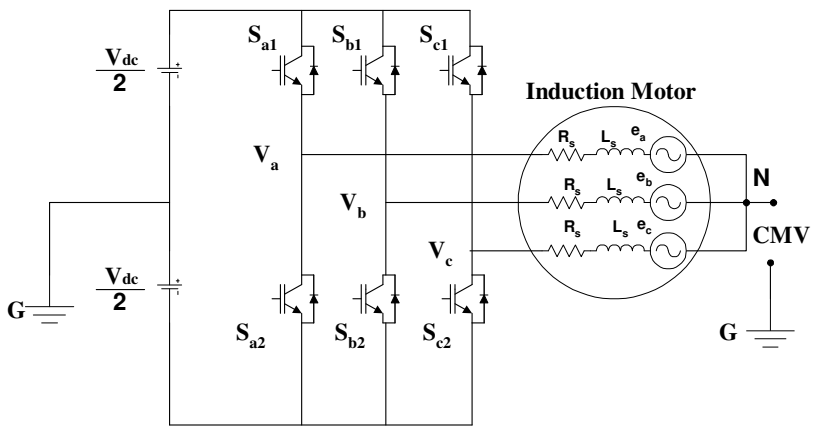

Fig.1 Generalised Drive System

$$
\begin{aligned}
& C M V=V_{n g}=\frac{V_{a g}+V_{b g}+V_{c g}}{3} \\
& C M V=V_{n g}=\frac{1}{3} \sum_{x=a}^{c} V_{x g}
\end{aligned}
$$

In purely sinusoidal three phase system sum of the instantaneous voltages at every time is zero hence CMV is zero. Voltage source inverter (VSI) output is not purely sinusoidal but discretised hence sum of the instantaneous voltage has non zero value which develops CMV.

If the switching function of the inverter is $S_{x}$ and $V_{d c}$ is dc voltage then phase voltage $V_{x g}$ can be expressed as- 
$V_{x g}=V_{d c}\left(S_{x}-\frac{1}{2}\right)$

In conventional three phase inverter when upper switch is on and lower switch is off $S_{x}=1$, in leg $\mathrm{x}$ of the inverter and vice versa. Combining above two equations CMV for conventional inverter is obtained as-

$$
C M V=\frac{V_{d c}}{3} \sum_{x=a}^{c} S_{x}-\frac{V_{d c}}{2} \ldots . \text { ForTwoLevel }
$$

In multilevel inverter as per the dc voltage level CMV can be expressed as

$$
\begin{aligned}
& C M V=\frac{1}{3}\left(S_{a}+S_{b}+S_{c}\right) \frac{V_{d c}}{2} \ldots . \text { ForThreeLevel } \\
& C M V=\frac{1}{3}\left(S_{a}+S_{b}+S_{c}\right) \frac{V_{d c}}{4} \ldots . \text { ForFiveLevel } \\
& C M V=\frac{1}{3}\left(S_{a}+S_{b}+S_{c}\right) \frac{V_{d c}}{6} \ldots . \text { ForSevenLevel }
\end{aligned}
$$

\section{Bearing Voltage, Shaft voltage, Bearing Current and PARASITIC CAPACITANCES IN INVERTER DRIVEN MOTOR}

The potential difference between inner and outer race of a bearing is called as bearing voltage $\left(\mathrm{V}_{\mathrm{b}}\right)$. The standard machine has two ends - Drive End (DE) and Non Drive End (NDE). Hence two bearing voltages are defined, voltage referred to drive end $\mathrm{V}_{\mathrm{b}} \mathrm{DE}$ and voltage referred to non drive end $\mathrm{V}_{\mathrm{b} \text { NDE}}$. In inverter-operation, when the CMV contains high frequency components and an intact lubricating film is formed between bearing balls and races then bearing acts as a capacitor. At this instant bearing voltage mirrors the common mode voltage at the motor terminals by a capacitive voltage divider [2], [3].

Shaft voltage $\left(\mathrm{V}_{\mathrm{sh}}\right)$ of a machine is the potential difference of the shaft between drive and non drive end [10].

Variable frequency drives have numerous benefits such as they offer energy savings and at the same time they allow high dynamic operation. Unfortunately they are also a source of new kind of bearing currents. These inverter generated bearing currents may destroy bearings within a short period of operation.

Parasitic capacitances of an electric motor provide low impedance paths for high frequency currents. These parasitic capacitances can be neglected at normal operating frequencies but at high carrier frequency and dv/dt these capacitances become significant. The main parasitic capacitances that have effect on bearing currents are stator winding to frame capacitance $\left(\mathrm{C}_{\mathrm{sf}}\right)$, stator winding to rotor capacitance $\left(\mathrm{C}_{\mathrm{sr}}\right)$, rotor to frame capacitance $\left(\mathrm{C}_{\mathrm{rf}}\right)$ and the bearing capacitance $\left(\mathrm{C}_{\mathrm{b}}\right)[3,4]$. These are shown in Fig. 2

These capacitances form a capacitive voltage divider as shown in Fig. 3. High frequency CMV at motor terminals is mirrored over the bearing by this voltage divider causing bearing voltage $\left(\mathrm{V}_{\mathrm{b}}\right)$. The ratio of bearing voltage to common mode voltage at motor terminals is defined as Bearing Voltage Ratio (BVR) [3]. Drive end bearing capacitance $\mathrm{Cb}_{\mathrm{DE}}$ is assumed to be equal to non drive end bearing capacitance $\mathrm{Cb}_{\mathrm{NDE}}$ i.e. $\quad \mathrm{Cb}_{\mathrm{DE}}=\mathrm{Cb}_{\mathrm{NDE}}=\mathrm{C}_{\mathrm{b}}$. From Fig. $3 \mathrm{BVR}$ can be expressed as 


$$
B V R=\frac{V_{b}}{C M V}=\frac{C_{s r}}{C_{s r}+C_{\text {rf }}+2 C_{b}}
$$

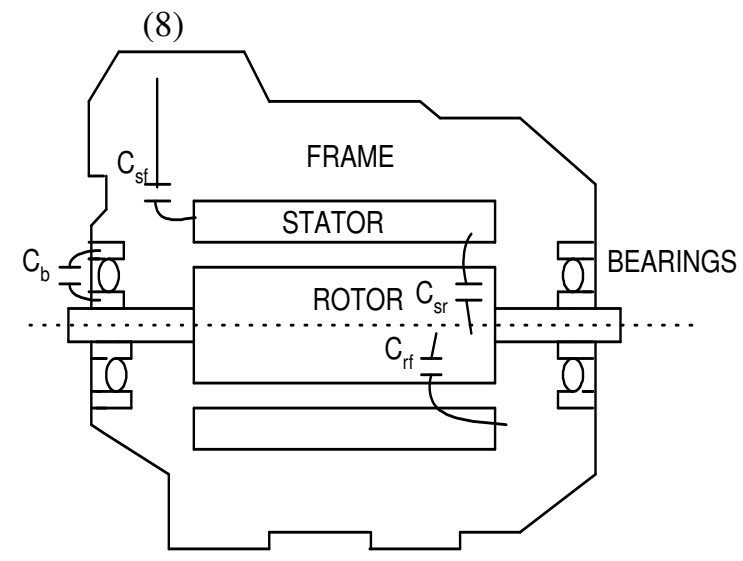

Fig. 2 Various Parasitic Capacitances of Induction Motor

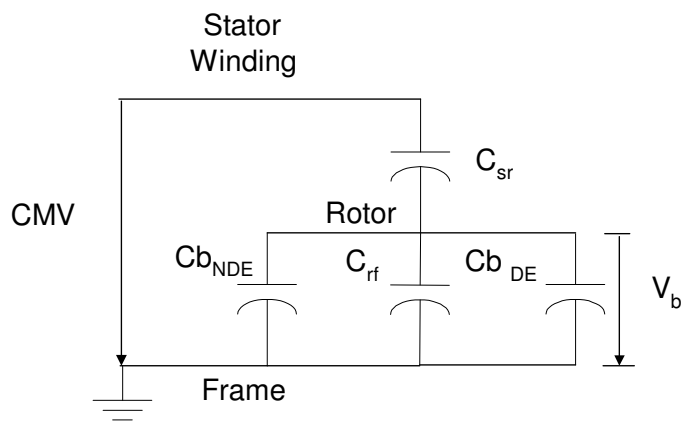

Fig. 3 Capacitive Voltage Divider

\section{EXPERIMENTAL DETERMINATION OF INDUCTION MOTOR Capacitances}

Equivalent circuit of inverter driven induction motor is shown in Fig.4. In this circuit switch represent the non linear behaviour of bearing capacitance. When bearing voltage becomes greater than dielectric strength of lubricant film in the bearing, electric breakdown of film takes place and this condition is represented by closing switch. This current is called as electric discharge machining bearing current. When bearing voltage is less than breakdown voltage then switch is kept opened, at this instant bearing current without discharge is obtained. With reference to this circuit various parasitic capacitances of the induction motor are measured using LCR meter as shown in Fig. 5. These can be measured as under:

\subsection{Stator winding to frame capacitance $\left(\mathrm{C}_{\mathrm{sf}}\right)$}

It can be measured by LCR meter. The LCR meter is connected between common terminal of stator winding and stator frame. While measuring this, rotor is removed from the motor to reduce the effect of rotor capacitances. It is measured to be $3798 \mathrm{pF}$. 


\subsection{Stator winding to rotor capacitance $\left(\mathrm{C}_{\mathrm{sr}}\right)$}

The rotor shaft and the frame are short circuited. Now LCR meter is connected between three commonly connected stator terminals and the machine frame. The total capacitance measured is ( $\mathrm{C}_{\mathrm{sr}} \| \mathrm{C}_{\mathrm{sf}}$ ). Hence $\mathrm{C}_{\mathrm{sr}}$ is obtained by subtracting measured value of $\mathrm{C}_{\mathrm{sf}}$ from capacitance reading of LCR meter. It is equal to $40 \mathrm{pF}$.

\subsection{Rotor to frame capacitance $\left(\mathrm{C}_{\mathrm{rf}}\right)$}

This is measured between motor shaft and motor frame with rotor stationary. The total capacitance measured is $\left(\mathrm{C}_{\mathrm{sf}}+\mathrm{C}_{\mathrm{sr}}\right) \|\left(\mathrm{C}_{\mathrm{rf}} \| \mathrm{C}_{\mathrm{ins}}\right)$. As $\mathrm{C}_{\mathrm{sr}}$ is very very small, the meter reading is $\left(\mathrm{C}_{\mathrm{rf}} \|\right.$ $\mathrm{C}_{\text {ins }}$ ). It is found to be $999 \mathrm{pF}$. Insulation capacitor between outer race and frame $\mathrm{C}_{\text {ins }}$ is measured by short circuiting motor shaft with motor frame and measuring the capacitance between outer race and motor frame with LCR meter when motor is stationary. It is found to be $122 \mathrm{pF}$. Hence $\mathrm{C}_{\mathrm{rf}}$ is equal to $877 \mathrm{pF}$.

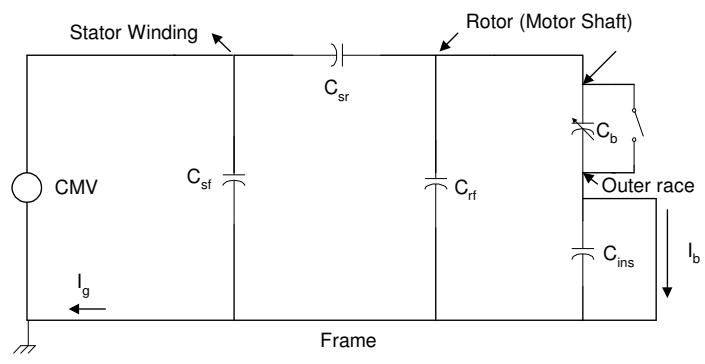

Fig. 4. Equivalent circuit of the Inverter driven motor

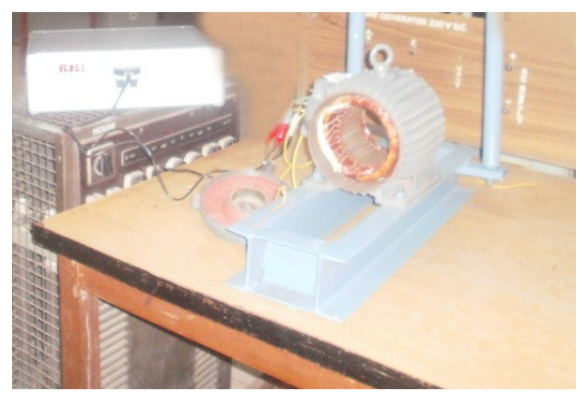

Fig.5. Experimental Determination of parasitic capacitances

\subsection{Bearing capacitance $\left(C_{b}\right)$}

It depends upon dielectric characteristics, resistivity and temperature of the lubricant, geometrical construction of bearing, dynamics of the asperity contact of the balls with race and speed of the rotor, etc.

Hence $\mathrm{C}_{\mathrm{b}}$ is a dynamic and depends upon the operating condition of the machines. Motor is driven at rated speed on no load. The motor is rotated at no load, now the supply is switched off and the capacitance value is measured between outer race and the shaft with LCR meter. It is 
Table 1. Specifications and measured values of capacitances

\begin{tabular}{|c|c|}
\hline $\begin{array}{c}\text { Specification / parasitic } \\
\text { capacitances }\end{array}$ & Value \\
\hline Line Voltage & $400 \mathrm{~V}$ \\
\hline Power & $2.2 \mathrm{~kW}$ \\
\hline Speed & $1440 \mathrm{rpm}$ \\
\hline Pole & 4 \\
\hline $\mathbf{C}_{\mathbf{s f}}$ & $3798 \mathrm{pF}$ \\
\hline $\mathbf{C}_{\mathbf{s r}}$ & $40 \mathrm{pF}$ \\
\hline $\mathbf{C}_{\mathbf{r f}}$ & $877 \mathrm{pF}$ \\
\hline $\mathbf{C}_{\mathbf{b}}$ & $98.77 \mathrm{pF}$ \\
\hline
\end{tabular}

measured before the motor speed reaches below $250 \mathrm{rpm}$. This measured value gives $\mathrm{C}_{3}=\mathrm{C}_{\mathrm{b}} / /($ $\mathrm{C}_{\mathrm{ins}}+\mathrm{C}_{\mathrm{rf}}$ ), knowing all $\mathrm{C}_{\mathrm{b}}$ can be calculated as $98.77 \mathrm{pF}$

Motor specification, rating and parasitic capacitances measured in the laboratory are given in Table 1.

\section{Modulation TechniQues}

The main modulation techniques in multilevel inverters are summarized as [9] -

1. Sinusoidal Pulse Width Modulation (SPWM)

2. Space Vector Pulse Width Modulation (SVPWM)

3. Selective Harmonic Elimination Pulse Width Modulation (SHEPWM)

First technique can be easily applicable to multilevel inverter by digital controller as it does not require any computations. Second and third techniques are complicated as they need some extra computations. In this paper focus is on the first method. Number of carrier signals required for ' $m$ ' level inverter is (m-1). Frequency and peak to peak amplitude of all the carrier waves should be same. SPWM can be again classified according to the phase position of the triangular carrier waveforms [7].

1. Phase Disposition (PD) - All carriers are in phase with one another.

2. Phase Opposite Disposition (POD) - Carriers above zero reference are in phase but in opposition to those below.

3. Alternate Phase Opposite Disposition (APOD) - As the name indicate carriers in alternate layers are in phase opposition.

\section{InVERTER DRIVEN MOtOR MOdel USing MATlab Simulink AND SIMULATION RESULTS}

A diode clamped multilevel inverter is used since it requires only one dc source, it can be easily used in industries for medium voltage applications. The study has been carried out with $3 \mathrm{hp}, 400$ Volt, three phase, four pole squirrel cage induction motor. The values of parasitic capacitances are taken as measured above. One of the serious issue of diode clamped multilevel inverter is dcbus voltage unbalancing. Since voltage balancing is not concern with this work separate dc sources have been provided for dc buses. The detailed study has been carried out with the simulation model as shown in Fig. 7. The results are taken by driving the motor with conventional two level, three level, five level and seven level inverter. Carrier frequency for all inverter models is $1050 \mathrm{~Hz}$. and motor is operated at $50 \mathrm{~Hz}$. 
Electrical and Electronics Engineering: An International Journal (ELELIJ) Vol 4, No 1, February 2015

\subsection{Two-Level Inverter Fed Induction Motor}

This inverter is simple to design with minimum components very simple control. The drawbacks are more harmonics distortion (THD) in line current and voltages. CMV is very high which results in large bearing current and shaft voltage. Fig. 6 shows the schematic of two level inverter fed induction motor drive.

Modulated reference sinusoidal $\mathrm{V}_{\text {ref }}$ is compared with triangular carrier wave $\mathrm{V}_{\text {tri }}$. When $\mathrm{V}_{\text {ref }}>$ $\mathrm{V}_{\text {tri }}$ then triggering pulses are generated and given to respective semiconductor switch.

Fig.7 shows the simulink model of inverter fed induction motor drive. The corresponding line voltage, phase voltage, line current, THD component of line voltage, common mode voltage, shaft voltage and bearing current with and without electrostatic discharge machining currents are shown in Fig. 8.

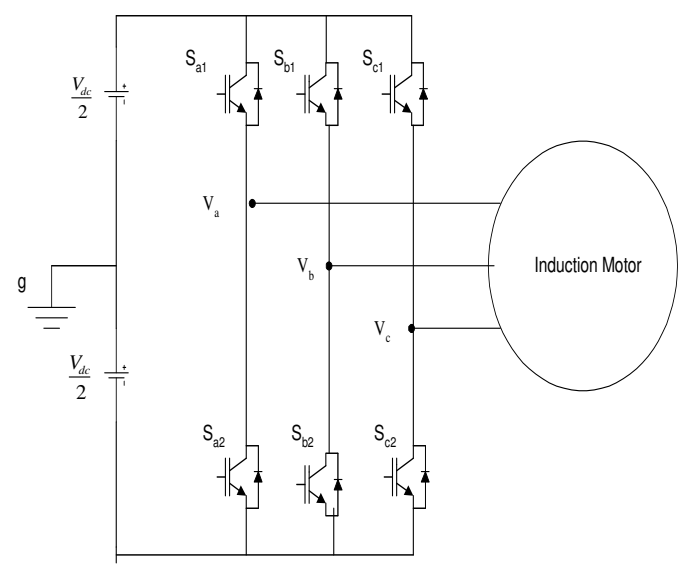

Fig.6. Schematic of two level inverter driven IM

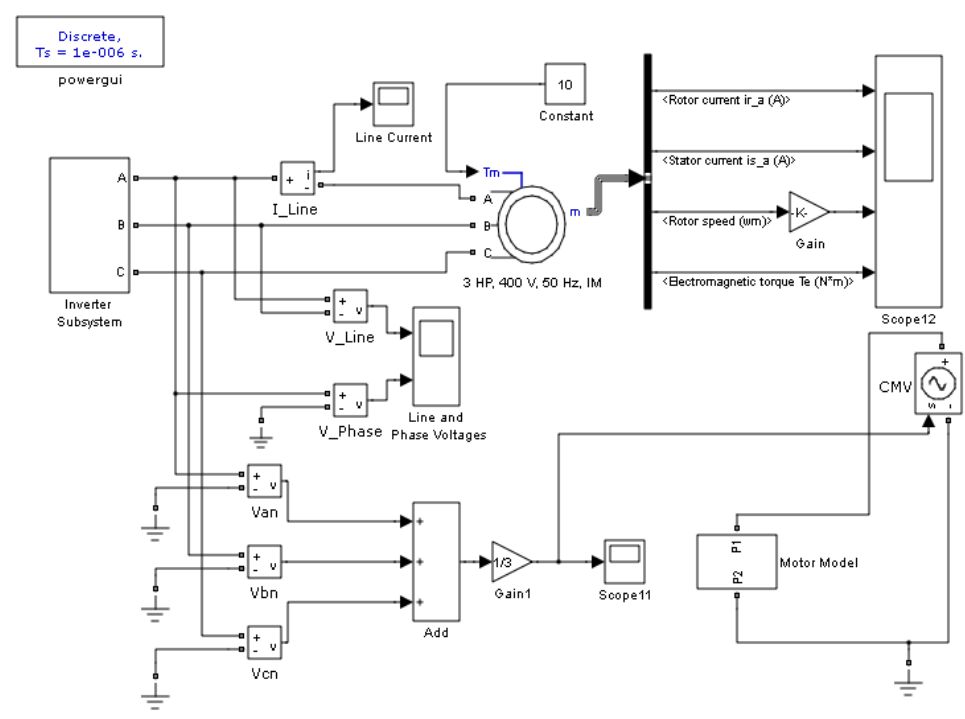

Fig. 7 Simulink model of inverter fed Induction Motor 


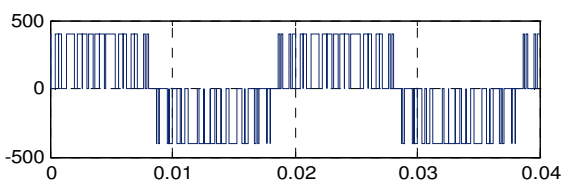

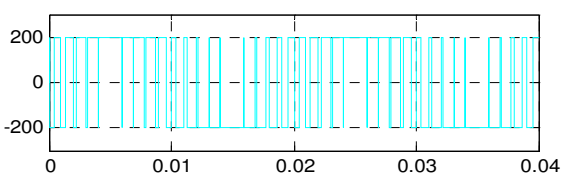

(a) Phase and Line voltages

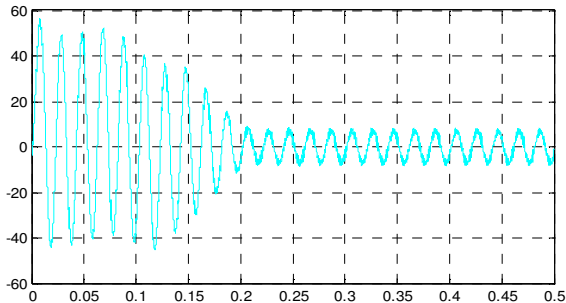

(c) ) Stator Current

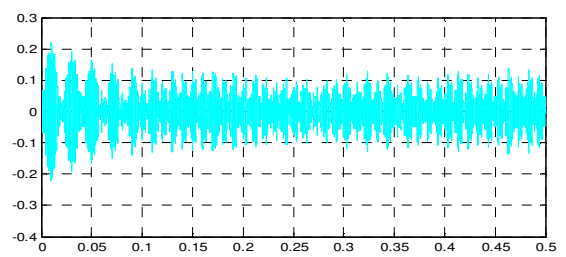

(e) Bearing Current with EDM

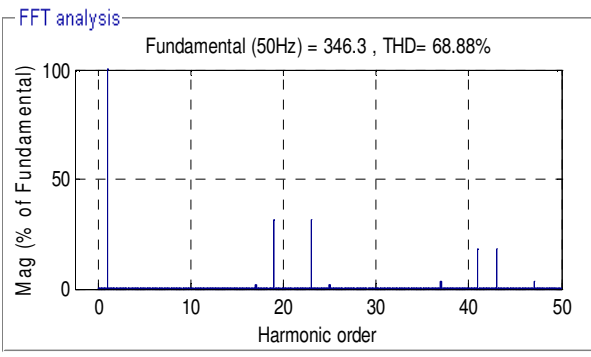

(b) Total Harmonic Distortion of Line Voltage
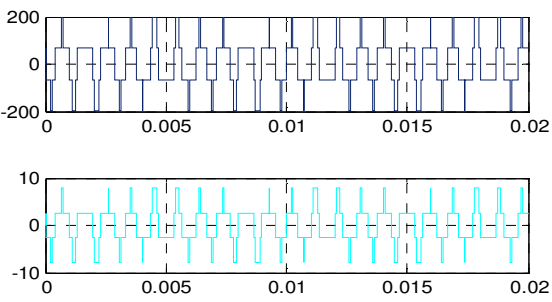

(d) Common Mode Voltage and Shaft Voltage

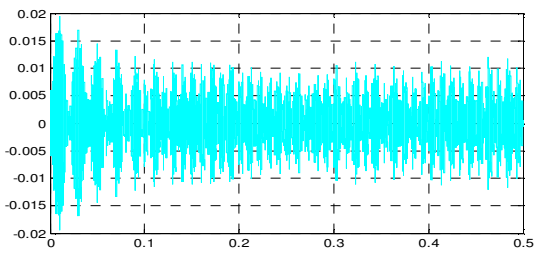

(f) Bearing Current with EDM

Fig. 8 Various results of Two Level Inverter (a)Phase and Line voltages, (b) Total Harmonic Distortion of Line Voltage,(c) Stator Current,(d)Common Mode Voltage and Shaft Voltage, (e)Bearing Current with EDM and (f) Bearing Current without EDM

\subsection{Three-Level Inverter Fed Induction Motor}

Fig. 9 shows the schematic of three-level inverter fed induction motor drive. It needs four IGBTs in each limb. There are total 12 IGBTs. $S_{\mathrm{a} 1}$ and $\mathrm{S}_{\mathrm{a} 2}$ are the switches in the upper half of the first limb and $S_{a 3}$ and $S_{a 4}$ are the switches in the lower half of the first limb. Table 2 shows the switching state, switching function and magnitude of output voltage for three level inverter. The corresponding line voltage, phase voltage, line current, THD component of line voltage, common mode voltage, shaft voltage and bearing current with and without electrostatic discharge machining currents are shown in Figure 10. 
Electrical and Electronics Engineering: An International Journal (ELELIJ) Vol 4, No 1, February 2015

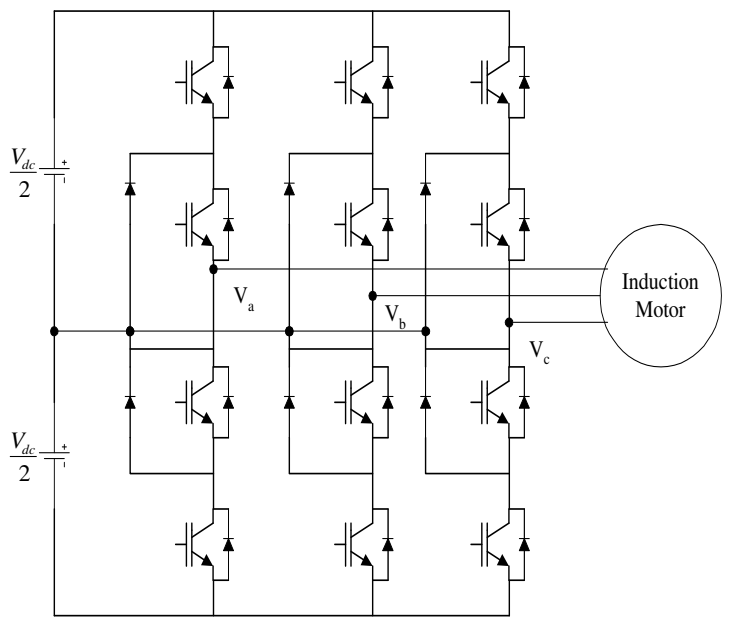

Fig. 9 Schematic of three level inverter

Table 2, Switching States of Three-Level Inverter

\begin{tabular}{|c|c|c|c|c|c|}
\hline \multirow{2}{*}{$\begin{array}{c}\text { Output } \\
\text { Voltage }\end{array}$} & \multicolumn{4}{|c|}{ Switching State } & \multirow{2}{*}{$\begin{array}{l}\text { Switching } \\
\text { Function }\end{array}$} \\
\hline & $S_{a I}$ & $S_{a 2}$ & $S_{a 3}$ & $S_{a 4}$ & \\
\hline $\mathrm{V}_{\mathrm{dc}} / 2$ & 1 & 1 & 0 & 0 & 1 \\
\hline 0 & 0 & 1 & 1 & 0 & 0 \\
\hline$-\mathrm{V}_{\mathrm{dc}} / 2$ & 0 & 0 & 1 & 1 & -1 \\
\hline
\end{tabular}
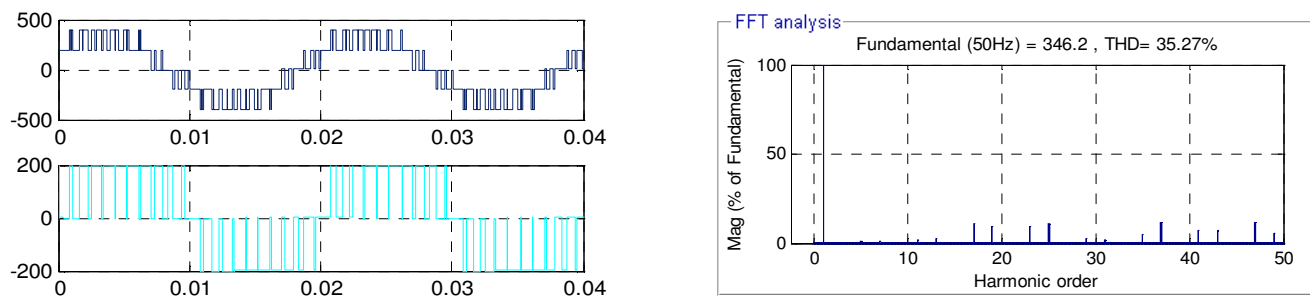

(a) Phase and Line voltages

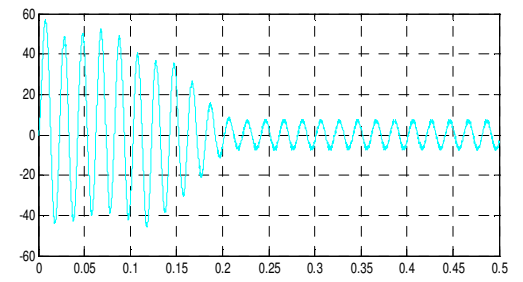

(c) Stator Current

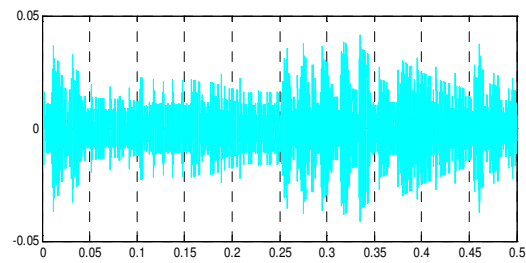

(e) Bearing Current with EDM
(b)Total Harmonic Distortion of Line Voltage

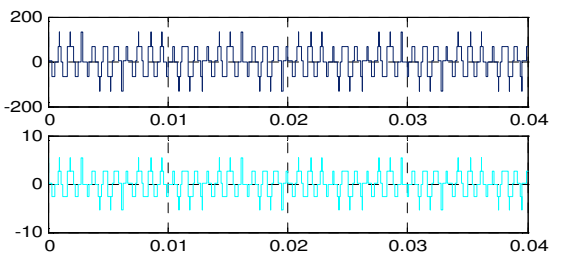

(d) Common Mode Voltage and Shaft Voltage

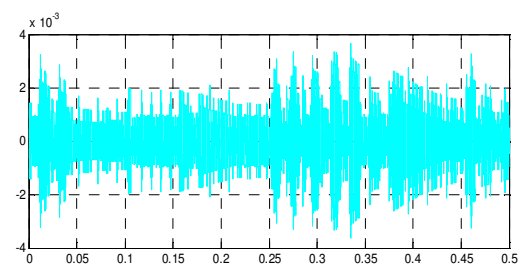

(f) Bearing Current without EDM

Fig. 10 Various results of Three Level Inverter (a)Phase and Line voltages, (b) Total Harmonic Distortion of Line Voltage, (c) Stator Current, (d)Common Mode Voltage and Shaft Voltage, (e) Bearing Current with EDM and (f) Bearing Current without EDM 


\subsection{Five-Level Inverter Fed Induction Motor}

Figure 11 shows the schematic of five-level inverter fed induction motor drive. It needs eight IGBTs in each limb. There are total 24 IGBTs. $S_{\mathrm{a} 1}, \mathrm{~S}_{\mathrm{a} 2}, \mathrm{~S}_{\mathrm{a} 3}$ and $\mathrm{S}_{\mathrm{a} 4}$ are the switches in the upper half of the first limb and $S_{a 5}, S_{a 6}, S_{a 7}$ and $S_{a 8}$ are the switches in the lower half of the first limb. Table 3 shows the switching state, switching function and magnitude of output voltage for five level inverter. The corresponding line voltage, phase voltage, line current, THD component of line voltage, common mode voltage, shaft voltage and bearing current with and without electrostatic discharge machining currents are shown in Figure 12.

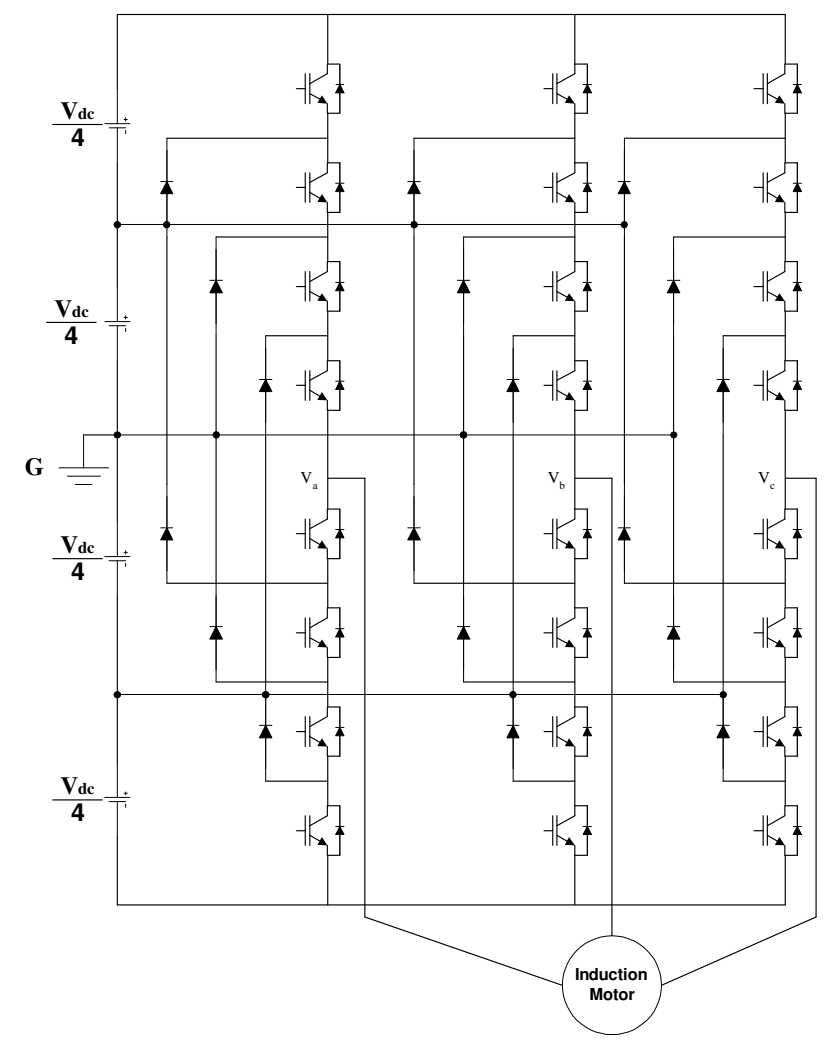

Fig.11 Schematic of Five Level Induction Motor Drive

Table 3, Switching States of Five-Level Inverter

\begin{tabular}{|c|c|c|c|c|c|c|c|c|c|}
\hline \multirow{2}{*}{$\begin{array}{c}\text { Output } \\
\text { Pole } \\
\text { Voltage }\end{array}$} & \multicolumn{8}{|c|}{ Switching State } & \multirow{2}{*}{$\begin{array}{l}\text { Switching } \\
\text { Function }\end{array}$} \\
\hline & $\mathbf{S}_{\mathrm{a} 1}$ & $\mathbf{S}_{\mathrm{a} 2}$ & $\mathbf{S}_{\mathrm{a} 3}$ & $\mathbf{S}_{\mathrm{a} 4}$ & $S_{a 5}$ & $\mathbf{S}_{\mathrm{a} 6}$ & $\overline{S_{\mathrm{a} 7}}$ & $\mathbf{S}_{\mathrm{a} 8}$ & \\
\hline $\mathrm{V}_{\mathrm{dc}} / 2$ & 1 & 1 & 1 & 1 & 0 & 0 & 0 & 0 & 2 \\
\hline $\mathrm{V}_{\mathrm{dc}} / 4$ & 0 & 1 & 1 & 1 & 1 & 0 & 0 & 0 & 1 \\
\hline 0 & 0 & 0 & 1 & 1 & 1 & 1 & 0 & 0 & 0 \\
\hline$-\mathrm{V}_{\mathrm{dc}} / 4$ & 0 & 0 & 0 & 1 & 1 & 1 & 1 & 0 & -1 \\
\hline$-\mathrm{V}_{\mathrm{dc}} / 2$ & 0 & 0 & 0 & 0 & 1 & 1 & 1 & 1 & -2 \\
\hline
\end{tabular}


Electrical and Electronics Engineering: An International Journal (ELELIJ) Vol 4, No 1, February 2015
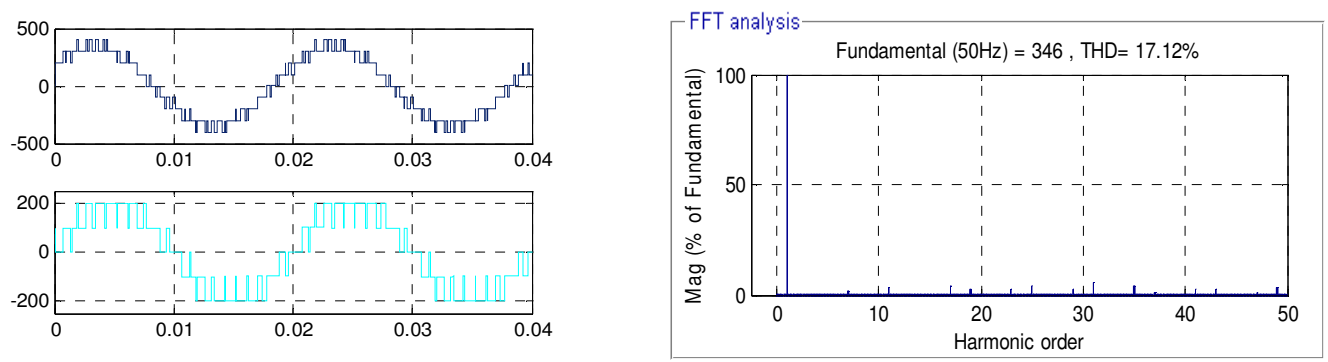

(a) Phase and Line voltages

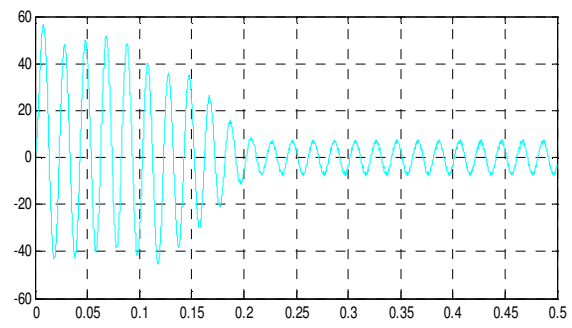

(b)Total Harmonic Distortion of Line Voltage

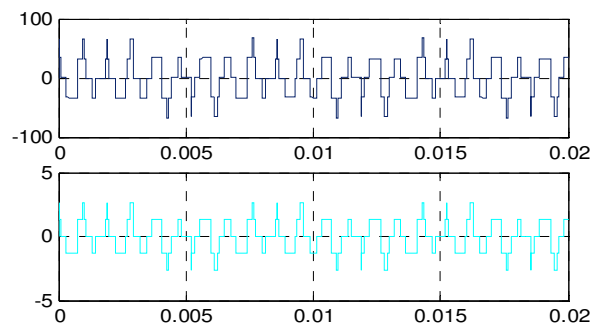

(c) Stator Current

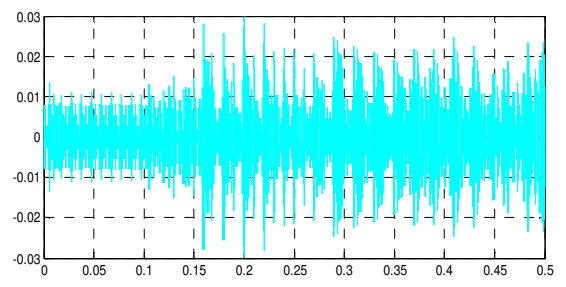

(d) Common Mode Voltage and Shaft Voltage

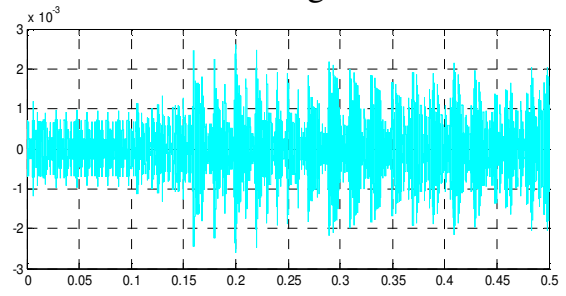

(e) Bearing Current with EDM

Fig. 12 Various results of Five Level Inverter (a)Phase and Line voltages, (b) Total Harmonic Distortion of Line Voltage, (c) Stator Current, (d)Common Mode Voltage and Shaft Voltage, (e) Bearing Current with EDM and (f) Bearing Current without EDM

\subsection{Seven-Level Inverter Fed Induction Motor}

Figure 13 shows the schematic of seven-level inverter fed induction motor drive. It needs twelve IGBTs in each limb. There are total 36 IGBTs. $S_{a 1}, S_{a 2}, S_{a 3}, S_{a 4}, S_{a 5}$ and $S_{a 6}$ are the switches in 
Electrical and Electronics Engineering: An International Journal (ELELIJ) Vol 4, No 1, February 2015

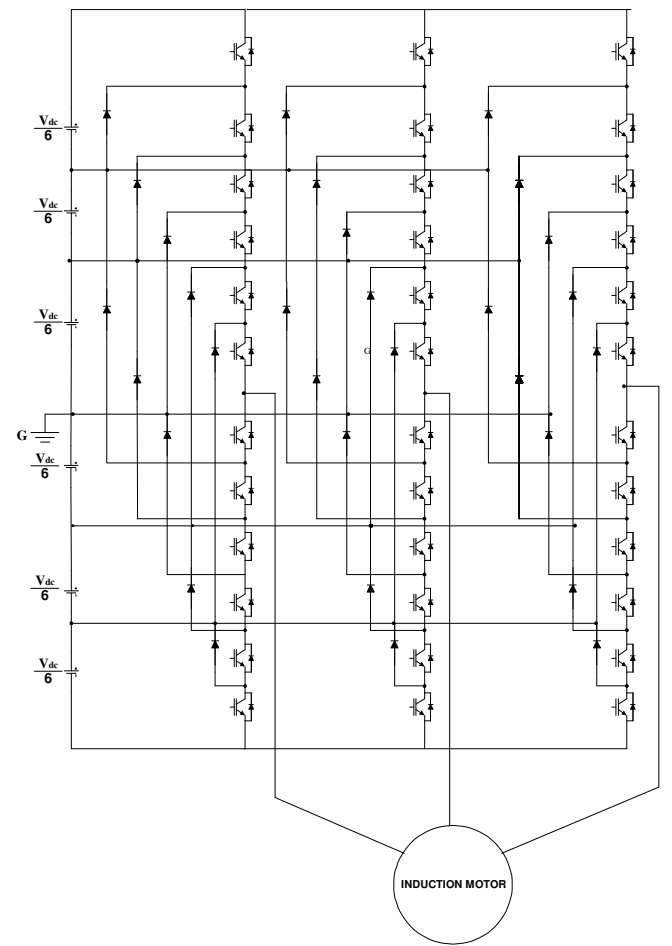

Fig.13 Schematic of Seven Level Inverter Induction Motor Drive

the upper half of the first limb and $\mathrm{S}_{\mathrm{a} 7}, \mathrm{~S}_{\mathrm{a} 8}, \mathrm{~S}_{\mathrm{a} 9}, \mathrm{~S}_{\mathrm{a} 10}, \mathrm{~S}_{\mathrm{a} 11}$ and $\mathrm{S}_{\mathrm{a} 12}$ are the switches in the lower half of the first limb. Table 4 shows the switching state, switching function and magnitude of output voltage for seven level inverter. The corresponding line voltage, phase voltage, line current, THD component of line voltage, common mode voltage, shaft voltage and bearing current with and without electrostatic discharge machining currents are shown in Fig. 14.

Table 4, Switching States of Seven-Level Inverter

\begin{tabular}{|c|c|c|c|c|c|c|c|c|c|c|c|c|c|}
\hline \multirow{2}{*}{$\begin{array}{c}\text { Output } \\
\begin{array}{c}\text { Pole } \\
\text { Voltage }\end{array}\end{array}$} & $\mathbf{S}_{\mathbf{a} 1}$ & $\mathbf{S}_{\mathbf{a} 2}$ & $\mathbf{S}_{\mathbf{a} \mathbf{3}}$ & $\mathbf{S}_{\mathbf{a} 4}$ & $\mathbf{S}_{\mathbf{a} 5}$ & $\mathbf{S}_{\mathbf{a} 6}$ & $\mathbf{S}_{\mathbf{a} 7}$ & $\mathbf{S}_{\mathbf{a} 8}$ & $\mathbf{S}_{\mathbf{a} \mathbf{9}}$ & $\mathbf{S}_{\mathbf{a} 10}$ & $\mathbf{S}_{\mathbf{a} 11}$ & $\mathbf{S}_{\mathbf{a} 12}$ & $\begin{array}{c}\text { Switching } \\
\text { Function }\end{array}$ \\
\hline $\mathrm{V}_{\mathrm{dc}} / 2$ & 1 & 1 & 1 & 1 & 1 & 1 & 0 & 0 & 0 & 0 & 0 & 0 & 3 \\
\hline $\mathrm{V}_{\mathrm{dc}} / 3$ & 0 & 1 & 1 & 1 & 1 & 1 & 1 & 0 & 0 & 0 & 0 & 0 & 2 \\
\hline $\mathrm{V}_{\mathrm{dc}} / 6$ & 0 & 0 & 1 & 1 & 1 & 1 & 1 & 1 & 0 & 0 & 0 & 0 & 1 \\
\hline 0 & 0 & 0 & 0 & 1 & 1 & 1 & 1 & 1 & 1 & 0 & 0 & 0 & 0 \\
\hline$-\mathrm{V}_{\mathrm{dc}} / 6$ & 0 & 0 & 0 & 0 & 1 & 1 & 1 & 1 & 1 & 1 & 0 & 0 & -1 \\
\hline$-\mathrm{V}_{\mathrm{dc}} / 3$ & 0 & 0 & 0 & 0 & 0 & 1 & 1 & 1 & 1 & 1 & 1 & 0 & -2 \\
\hline$-\mathrm{V}_{\mathrm{dc}} / 2$ & 0 & 0 & 0 & 0 & 0 & 0 & 1 & 1 & 1 & 1 & 1 & 1 & -3 \\
\hline
\end{tabular}

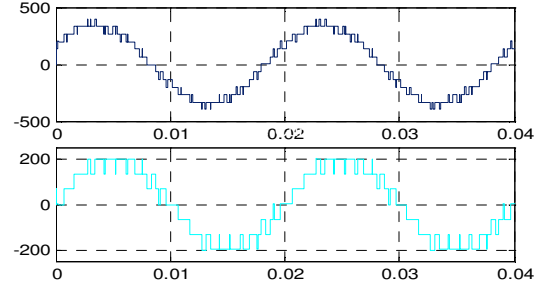

(a) Phase and Line voltages

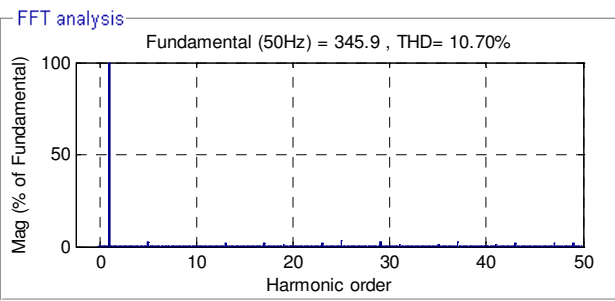

(b) Total Harmonic Distortion of Line Voltage 


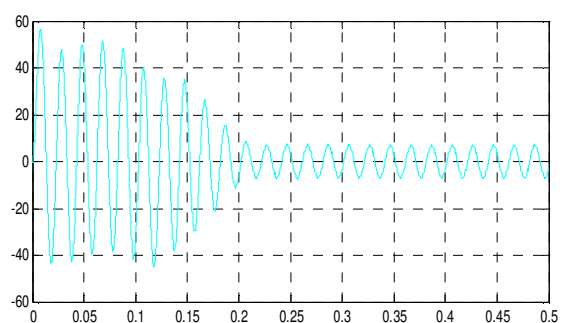

(c) Stator Current

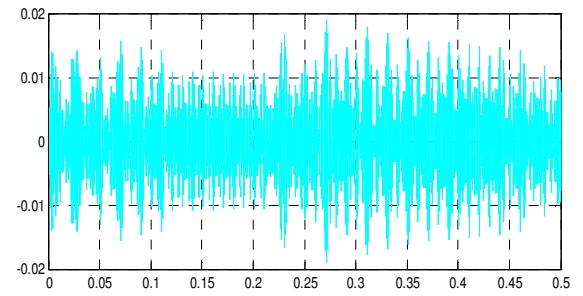

(e)Bearing Current with EDM

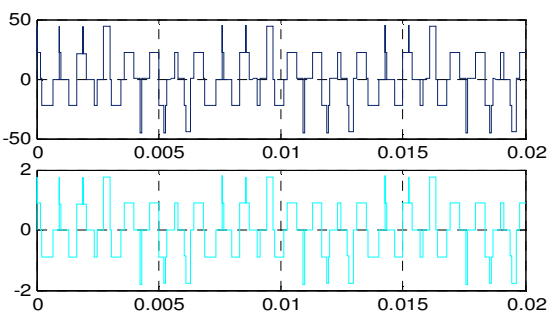

(d) Common Mode Voltage and Shaft Voltage

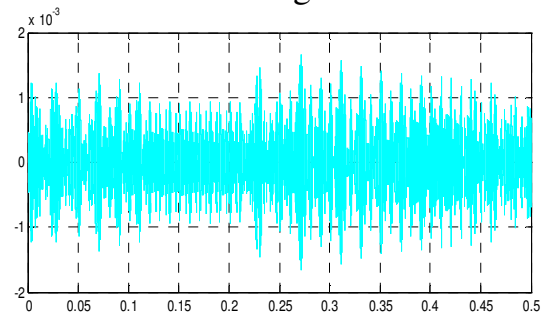

(f) Bearing Current without EDM

Fig. 14 Various results of Seven Level Inverter (a)Phase and Line voltages, (b) Total Harmonic Distortion of Line Voltage, (c) Stator Current, (d)Common Mode Voltage and Shaft Voltage, (e) Bearing Current with EDM and (f) Bearing Current without EDM

\subsection{Discussion on Results}

Fig.8, 10, 12 and 14 shows the results of induction motor drive fed by two, three, five and seven level inverter. From the results it is observed that as the level of inverter increases CMV, bearing current with and without EDM, \% THD decreases. Increase in level improves the nature of output voltage waveform, approaching to sinusoidal shape which in turn reduces lower order harmonics decreasing THD. The number of steps in the output voltage increases as the level increases which reduces rate of rise of voltage. Due to decrease in step size of output voltage CMV and magnitude of bearing currents also decreases. As the level of inverter increases the performance of motor improves but due to increase in switches and their controlling devices the circuitry becomes complicated. Table 5 summarises all simulated results.

Table - 5 Values of Common Mode Voltage, Shaft Voltage and Bearing Current with Short circuited Non linear resistance

\begin{tabular}{|c|c|c|c|c|c|}
\hline $\begin{array}{c}\text { Level of } \\
\text { Inverter }\end{array}$ & $\begin{array}{c}\text { \% THD } \\
\text { content of } \\
\text { Line } \\
\text { Voltage }\end{array}$ & $\begin{array}{c}\text { Peak value of } \\
\text { Common } \\
\text { Mode Voltage } \\
(\mathbf{V})\end{array}$ & $\begin{array}{c}\text { Peak } \\
\text { value of } \\
\text { Bearing } \\
\text { Voltage } \\
\text { (V) }\end{array}$ & $\begin{array}{c}\text { Peak value of } \\
\text { Bearing } \\
\text { Current } \\
\text { Without EDM } \\
(\mathbf{m A})\end{array}$ & $\begin{array}{c}\text { Peak value of } \\
\text { Bearing } \\
\text { Current with } \\
\text { EDM (mA) }\end{array}$ \\
\hline $\begin{array}{c}\text { Two Level } \\
\text { Inverter }\end{array}$ & 68.88 & 200 & 8 & 19.4 & 222.2 \\
\hline $\begin{array}{c}\text { Three Level } \\
\text { Inverter }\end{array}$ & 35.27 & 133.6 & 5.32 & 3.635 & 41.6 \\
\hline $\begin{array}{c}\text { Five Level } \\
\text { Inverter }\end{array}$ & 17.12 & 66.65 & 2.65 & 2.6 & 30 \\
\hline $\begin{array}{c}\text { Seven } \\
\text { Level } \\
\text { Inverter }\end{array}$ & 10.7 & 45.0 & 1.77 & 1.656 & 18.9 \\
\hline
\end{tabular}




\section{CONCLUSION}

This paper proposes a simple MATLAB simulink model for a comprehensive study on CMV, shaft voltage and bearing current with and without EDM of multilevel inverter fed three phase induction motor.

It is observed that in conventional inverter bearing current, bearing voltage, CMV and THD contents have maximum values. As the level of inverter increases these quantities start decreasing. Table 5 gives the combine results of all inverter fed induction motor. In conventional inverter $C M V$ varries between $\pm V_{\mathrm{dc}} / 2$. In three level it varries between $\pm \mathrm{V}_{\mathrm{dc}} / 3$. In five and seven level it varries between $\pm \mathrm{V}_{\mathrm{dc}} / 6$ and $\pm \mathrm{V}_{\mathrm{dc}} / 9$ respectively. THD also decrease to a considerable value of $10.7 \%$ From three level onwards the value of bearing current and shaft voltages are very less as compare to conventional inverter. It is observed that shaft voltages and CMV are the mirror image in all inverters. MLI gives high quality output as compare to conventional inverter at the cost of complexity in design.

\section{REFERENCES}

[1] G.Bhuvaneswari and Nagaraju, "Multi-Level Inverters - A Comparative Study," IETE Journal of Research, Vol.51, No. 2,pp.141-153, March-April 2005.

[2] Jay M.Erdman,R.J.Kerkman,D.W.Schlegel and G.L.Skibinski , "Effect of PWM Inverters on AC Motor Bearing currents and Shaft Voltages," IEEE Transactions on Industry Applications, Vol.32, No. 2 , pp.250- 259 , March/April 1996.

[3] Doyle Busse,Jay Eradman,R.J.Kerkman,Dave Schlegel and Gary Skibinski , "System Electrical Parameters and Their Effects on Bearing Currents," IEEE Transactions on Industry Applications ,Vol33, No.2, pp. 577-583, March/April1997

[4] H.Akagi and S.Tamura , "A Passive EMI Filter for Eliminating both Bearing Current and Ground Leakage Current from an Inverter-Driven Motor," IEEE Transactions on Power Electronics Vol.21,No.5, pp.1459-1469, September 2006

[5] R.S. Kanchan, P.N. Tekwani, M.R. Baiju, K. Gopakumar and A. Pittet, "Three-level Inverter Configuration with Common Mode Voltage Elimination for Induction Motor Drive," IEE Proc.Electr. Power Appl., Vol. 152, No. 2, pp.261-270, March 2005

[6] Alexander L. Julian, Giovanna Oriti, and Thomas A. Lipo, "Elimination of Common-Mode Voltage in Three-Phase Sinusoidal Power Converters," IEEE Transactions on Power Electronics Vol.14,No.5, pp.982-989, September 1999

[7] M.M.Renge and H.M.Suryawanshi , “Multilevel Inverter to Reduce Common Mode Voltage in AC Motor Drives Using SPWM Technique.” pp.21-27,Journal of Power Electronics, Vol. 11, No. 1, January 2011

[8] M.M.Renge and H.M.Suryawanshi , "Five-Level Diode Clamped Inverter to Eliminate Common Mode Voltage and Reduce dv/dt in Medium Voltage Rating Induction Motor Drives.", IEEE Transactions on Power Electronics ,Vol.23 , No. 4 , pp.1598-1607,July,2008

[9] José Rodríguez, Jih-Sheng Lai, and Fang Zheng Peng, "Multilevel Inverters: A Survey of Topologies, Controls, and Applications," IEEE Transactions on Industrial Electronics, Vol.49, No. 4 , pp. 724738,August, 2002

[10] U.T.Shami and Hirofumi Akagi , “Experimental Discussions on a Shaft End-to-End Voltage Appearing in an Inverter Driven Motor", IEEE Transactions on Power Electronics , Vol.24, No.6, pp.1532-1540,June2009

\section{Authors}

RajendraK.Dhatrak received the B.E. degree in electrical engineering from Government College of Engineering, Karad, India, in 1991and the M.Tech degree in design and production of heavy electrical equipment from Maulana Azad National Institute of Technology, Bhopal, India in 1998. He is currently pursuing the Ph.D. degree at Maulana

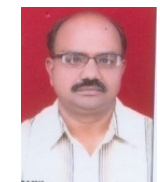


Azad National Institute of Technology, Bhopal, India. He is working as an Associate Professor in the Department of Electrical Engineering, at Rajiv Gandhi College of Engineering, Research and Technology, Chandrapur, India. His research interest includes electrical drives and multilevel inverter.

Rajesh K. Nema received his PhD degree in Electrical Engineering from Barkatullah University, Bhopal, India in 2004. He is currently Professor in the Department of Electrical Engineering, Maulana Azad National Institute of Technology, Bhopal, India. He has published many papers in National and International journals and conference.His current research interest include power conditioning unit for Renewable Energy storage system particularly Solar Energy, Hybrid Energy Systems, Grid Interconnection of

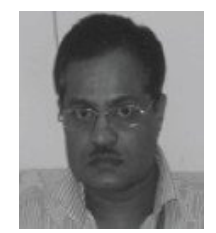
Renewable Energy sources, Electrical Drives.

Dinesh M. Deshpande received the B.E. degree in electrical engineering in 1970 and the M.Tech degree in integrated power system in 1972 from Visvesvaraya Regional College of Engineering, Nagpur, India. He has completed the PH.D. degree in 2002, from Barkatullah University, Bhopal, India. He was a Professor in Electrical Engineering at Maulana Azad National Institute of Technology, Bhopal, India. He is currently working as a Professor in the department of Electrical and Electronics Engineering at Sagar Institute of Research, Technology and Science, Bhopal, India. His

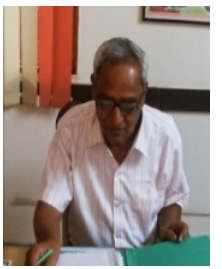
research area of interest is in power system and electrical drives. He has published many papers in National and International journals and conference. 